University of Rhode Island

DigitalCommons@URI

The Rhode Island Current Conditions Index

Economics

$11-2015$

\title{
Rhode Island Current Conditions Index - November 2015
}

Leonard Lardaro

University of Rhode Island, lardaro@uri.edu

Follow this and additional works at: https://digitalcommons.uri.edu/ricci

Part of the Econometrics Commons

Terms of Use

All rights reserved under copyright.

\section{Recommended Citation}

Lardaro, Leonard, "Rhode Island Current Conditions Index -- November 2015" (2015). The Rhode Island Current Conditions Index. Paper 143.

https://digitalcommons.uri.edu/ricci/143

This Article is brought to you for free and open access by the Economics at DigitalCommons@URI. It has been accepted for inclusion in The Rhode Island Current Conditions Index by an authorized administrator of DigitalCommons@URI.For more information, please contact digitalcommons-group@uri.edu. 


\title{
CURRENT CONDITIONS
}

LEONARD LARDARO, URI

\author{
Available Online: http:/ / www .Ilardaro.com/ current.htm \\ Blog: http:/ / rieconomy.blogspot.com \\ Twitter: @ladardo
}

VOL XXLI

NUMBER 12

NOV 2015
Rhode Island's economy improved a bit in November after getting off to a rather mediocre start to the fourth quarter. In October, the Current Conditions Index declined sharply from its September value of 83 to 67, which was a continuation of its downward trajectory from its August high of 92 . The $\mathrm{CCl}$ for November did manage to rebound a bit to 75 from its October value of 67 , as nine of the twelve indicators improved. Fortunately, even though November's $\mathrm{CCl}$ value remained well below its levels in both August and September, it did at least top its value from last November, the ninth time this year that the $\mathrm{CCl}$ has matched or exceeded its year-earlier value.

While there was some good news for November, it is apparent that Rhode Island's rate of growth continues to reflect the slowdown in growth nationally. The enhanced momentum we experienced during the third quarter appears to be dissipating as we move toward year's end. As has been true for several months now, much of the recent weakness is concentrated in our state's manufacturing sector. The one potential bright spot this month is that the recent deterioration in the monthly performance of a number of $\mathrm{CCl}$ indicators appeared not to occur in November, although this was manifested largely in labor market data that might be revised to portray something quite different with data rebenchmarking. We'll have to wait and see. So, at this point, it is safe to say that as the national economy slows, Rhode Island

\begin{tabular}{|l|r|}
\hline \multicolumn{2}{|c|}{ CCI Indicators - \% Change } \\
\hline Government Employment & -1.0 \\
\hline US Consumer Sentiment & $2.8 \mathrm{Y}$ \\
\hline Single-Unit Permits & $\mathbf{5 8 . 8} \mathrm{Y}$ \\
\hline Retail Sales & $2.3 \mathrm{Y}$ \\
\hline Employment Services Jobs & $6.3 \mathrm{Y}$ \\
\hline Priv. Serv-Prod Employment & $2.5 \mathrm{Y}$ \\
\hline Total Manufacturing Hours & $-\mathbf{1 . 4}$ \\
\hline Manufacturing Wage & -2.3 \\
\hline Labor Force & $1.1 \mathrm{Y}$ \\
\hline Benefit Exhaustions & $-11.5 \mathrm{Y}$ \\
\hline New Claims & $-\mathbf{1 7 . 9} \mathrm{Y}$ \\
\hline Unemployment Rate (change) & $-1.7 \mathrm{Y}$ \\
\hline \multicolumn{2}{|c|}{$\mathrm{Y}=$ Improved Value } \\
\hline
\end{tabular}

experiences the downdraft on its growth almost immediately.

Nine of the twelve $\mathrm{CCl}$ indicators improved in November Weakness was concentrated largely in our manufacturing sector and not throughout our entire goods-producing sector, as new home construction improved this month. As I have noted recently, I have yet to fully comprehend what is occurring with new home construction here. Total Manufacturing Hours, a measure of manufacturing sector strength, fell by 1.4 percent in November, its sixth decline in the last eight months. Along with this, the Manufacturing Wage declined yet again, this month by 2.3 percent.
Among November's nine improving indicators were four of the $\mathrm{CCl}$ 's five leading indicators. However, only two of the improving leading indicators managed to beat difficult comps from a year ago. The sole leading indicator that failed to improve, as discussed earlier, was Total Manufacturing Hours. New home construction, in terms of Single-Unit Permits, rose by an astonishing 58.8 percent compared to last November, partly the result of an exceedingly favorable comp from last year. Even with this improvement, November was only its fourth increase since April. US Consumer Sentiment increased once again, albeit at a slower rate than has been true recently $(+2.8 \%)$. This was its fourteenth consecutive improvement. Employment Service Jobs, which includes temporary employment and is a prerequisite to employment growth, rose by 6.3 percent, its highest rate in quite some time. Finally, New Claims, a leading labor market indicator that reflects layoffs, fell by $\mathbf{1 7 . 9}$ percent in November.

Retail Sales growth accelerated in November (+2.3\%), making this its eighteenth consecutive improvement. Private Service-Producing Employment rose by 2.5 percent in November. This is one of the indicators whose monthly growth rate did not deteriorate as it had recently. Government Employment fell again $(-1.0 \%)$. Benefit Exhaustions, which reflects longer-term unemployment, declined by 11.5 percent relative to last year. While our Labor Force managed to sustain its recent uptrend on a yearly but not monthly basis $(+1.1 \%)$, it remained well below its July value. Because of this, my major concern moving forward is that both our employment rate and labor force participation rates have continued to decline since July, with both remaining well below their recession levels. Once again, Rhode Island finds its Unemployment Rate falling for the wrong reasons, and any comparison of the current and 2007 jobless rates is purely spurious.
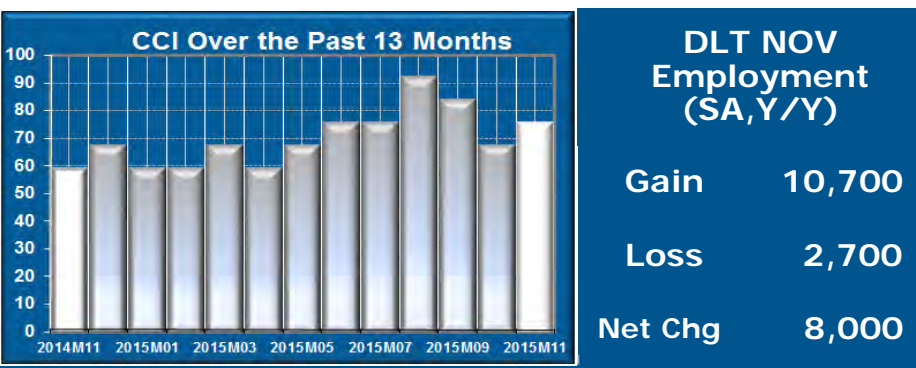

THE BOTTOM LINE

While the Current Conditions Index for November was well below the levels it attained in August and September, it did at least represent a bit of a rebound from its recent decline to 67 in October. As the national economy slows, so too does Rhode Island. It's too bad that the lag between the time national activity improves and its effects are felt in Rhode Island is much longer than is true for slowing growth. Clearly, remedying this asymmetry should be on the top of the legislative agenda this session and for a number of years to come.

\begin{tabular}{|c|c|c|c|c|c|c|c|c|c|c|c|c|c|}
\hline & & Jan & Feb & Mar & Apr & May & $J$ un & $\mathrm{J}$ ul & Aug & Sep & Oct & Nov & Dec \\
\hline & 2014 & 67 & $67 \uparrow$ & 58 & 58 & 58 & 50 & $67 \downarrow$ & $67 \downarrow$ & 75 & $67 \uparrow$ & 58 & $67 \downarrow$ \\
\hline & 2015 & 58 & 58 & 67 & 58 & 67 & 75 & 75 & 92 & 83 & 67 & 75 & \\
\hline
\end{tabular}

